\title{
ON THE EFFECT OF THE TANGENTIAL OFFSET OF BLADES ON THE POWER CHARACTERISTICS OF THE IMPELLER OF A SUPERSONIC COMPRESSOR STAGE
}

\author{
Institute of Technical Mechanics \\ of the National Academy of Sciences of Ukraine and the State Space Agency of Ukraine \\ 15 Leshko-Popel St., Dnipro 49005,Ukraine; e-mail: yukv@i.ua; zinevich7385@gmail.com
}

The aim of this paper is to computationally study the effect of the tangential offset of blades on the power characteristics of the impeller of a supersonic compressor stage. The main computational tool was the method for numerical simulation of 3D turbulent gas flows developed earlier at the Institute of Technical Mechanics of the National Academy of Sciences of Ukraine and the State Space Agency of Ukraine. As a result of a set of parametric calculations, it is shown that the introduction of a tangential offset may increase the adiabatic efficiency of the impeller with a simultaneous increase in the compression ratio. The distributions of the adiabatic efficiency along the passage height at the impeller outlet presented in this paper illustrate the increase in the impeller efficiency near the hub and the casing surface when a tangential offset is used. The paper demonstrates that in numerical studies efficient use can be made of specially chosen "coarse" meshes that, nevertheless, keep the sensitivity of the computed data to a variation of the blade shape. It is also shown that the impeller power characteristics can be estimated using their values averaged over the working range of the air flow rate through the impeller. The validity of this approach is confirmed by calculating on a fine mesh the power characteristics of an impeller with blades of a standard shape and a shape changed by the introduction of an offset. The results of this study may be used in the aerodynamic optimization of the $3 \mathrm{D}$ shape of compressor stator and rotor blades.

Keywords tangential offset of blades, compressor stage impeller, numerical simulation, uniformly distributed sequence, power characteristics.

1. Boyko A. V., Govorushchenko Yu. N., Burlaka M. V. Application of Computational Aerodynamics to Turbomachine Blade Optimization (in Russian). Kharkov: National Technical University "Kharkov Polytechnic Institute”, 2012. 191 pp.

2. Simon J. Gallimore, John J. Bolger, Nicholas A. Cumpsty, Mark J. Taylor, Peter I. Wright, James M. M. Place. The use of sweep and dihedral in multistage axial flow compressor blading. Part II: low and high speed designs and test verification. Journal of Turbomachinery. October 2002. Vol. 124. P. 533-541.

3. Shelkovsky M. Yu. Parametric study of the gas-dynamic characteristics of compressor cascades (in Russian). Aviatsionno-Kosmicheskaya Tekhnika i Tekhnologiya. 2012. No. 7(94). Pp. 95-106.

4. Serkov S. A., Sedunin V. A., Blinov V. L. Effect of parameter uniformity along the blade height of a highloaded axial compressor on its integral characteristics and gas-dynamic stability margin (in Russian). Proceedings of the $1^{\text {st }}$ Scientific and Technical Conference of of Ural Power Engineering Institute's Young Scientists. (Yekaterinburg, May 16 - 20, 2016). Yekaterinburg, 2016. Pp. 87-92.

5. Design and Overall Performance of Four Highly Loaded, High-Speed Inlet Stages for an Advanced HighPressure-Ratio Core Compressor : NASA Technical Paper 1337, 1978. 132 p.

6. Kvasha Yu. A. Calculation of a 3D turbulent flow in supersonic compressor stage blade passages (in Russian). Tekhnicheskaya Mekhanika. 1999. No. 1. Pp. 9-13.

7. Sobol I. M., Statnikov R. B. Choice of Optimum Parameters in Multicriteria Problems (in Russian). Moscow: Nauka, 1981. 110 pp.

8. Kvasha Yu. A., Zynevich N. A. On the aerodynamic optimization of supersonic compressor stage impellers (in Russian). Tekhnicheskaya Mekhanika. 2016. No. 2. Pp. 55-63.

9. Kvasha Yu. A., Zynevich N. A. On the choice of computational grids in numerical simulation of 3D turbulent flows in supersonic compressor stage impellers (in Russian). Tekhnicheskaya Mekhanika. 2013. No. 3. Pp. 34-41. 